\title{
Student Perceptions Towards the Use of the Mobile Flipped Classroom Approach
}

\author{
Siti Hajar Halili, University of Malaya, Kuala Lumpur, Malaysia \\ Norharyanti Mohsin, University of Malaya, Kuala Lumpur, Malaysia \\ Rafiza Abdul Razak, University of Malaya, Kuala Lumpur, Malaysia
}

\begin{abstract}
This study aimed at identifying students' perceptions in terms of motivation, learning, and engagement in using a mobile flipped classroom approach based on Kolb's learning cycle. This quantitative study was conducted using a questionnaire to collect the data. The collected data were analyzed using descriptive analysis (percentage, means, and standard deviations) utilizing the SPSS 20. The research took place in one of the top private universities in Malaysia and equipped with adequate free internet access. The researcher applied homogenous purposive sampling by selecting 40 undergraduate students registered in the multimedia and computer animation course. The result showed that students had positive perceptions in terms of students' motivation, learning, and engagement in multimedia and animation course using a mobile flipped classroom approach. Future research is recommended to focus on different age and a group of participants to obtain in-depth information on the implementation of mobile flipped classroom approach in a different context.
\end{abstract}

\section{KEYWORDS}

Augmented Reality, Engagement, Kolb's Learning Cycle, Learning, Mobile Flipped, Motivation, Multimedia and Animation Course, Students' Perceptions

\section{INTRODUCTION}

Flipped classroom (FC) is one of the pedagogical methods that have been taken place and attention in the educational field. According to Bates (2012), FC is a new approach where the teacher encourages students to study new topics outside the classroom, and conduct the activity or exercise in the classroom to strengthen students' understanding. It was introduced by Jonathan Bergmann and Aaron Sams (Bergmann \& Sams, 2011) to encourage active learning within students. In FC, they are using video recording to record lectures or slide presentations for students to learn before class starts; and complete tasks or discussion in class (Hamdan et al., 2013). According to Lage, Platt and Treglia, (2000), FC is also known as an inverted classroom. The inverted classroom is as same as FC where lectures and homework switch places; teachers taught students' outside class and students' finished their homework inside a class (Shibley, 2014). Goh (2012) reported that by applying FC, it encourages 
students to become active learners while the teacher becomes a facilitator to lead them during class discussion. This approach is to ensure that all students achieve meaningful and effective learning.

In the 1990s, mobile computing has been taking place in the era with the existence of Palm Pilot 1000 PDA and Psion 3 minicomputer (Finnegan, 2015). Nowadays, by introducing the smartphone and tablet, everyone now can access the technology; from the small kids up to the professional and veteran, depending on their needs and usage. Sharples et.al (2007) define mobile learning (ML) as the processes of coming to know through exploration and conversation across multiple contexts amongst people and interactive technologies. According to Yusoff and Sunar (2014), ML was defined as using mobile technologies or wireless devices for the role of learning on the move. While Norman et.al., (2015) mentioned that ML is learning the process with the use of mobile technology or mobile devices, which give an effect of the learning due to the small screen sizes compared to a normal computer. In this modern century, students are accessible to a smartphone, tablet, iPad and, etc. (Nagel, 2013). Idrus (2015) also agreed that the use of mobile phones becomes a great support to students via animation, simulation, and interactive capabilities.

There are many ways to adopt an FC approach into educational settings, and one of them is through ML, which involved mobile devices such as smartphones, tablets, and PDAs. Milrad et al., (2013) defined mobile flipped learning (MFL) is the student's ability to shift from one learning to set to another by using mobile devices. This is where the combination of mobile and flipped learning hit its stride.MFL is an approach when the mobile phone becomes a full technology in use and the learners that use the technology are also mobile when they intend to learn (El-Hussein \& Cronje, 2010).

\section{MOBILE FLIPPED LEARNING}

Researchers found that most of the studies related to FC done by researchers from other countries (Nederveld \& Berge, 2015; Simpson \& Richards. 2015; Touchton, 2015; Morgan, 2014; Tune et al., 2013; Milman, 2012; Sams \& Bergmann, 2012). From all the literature available, within the Malaysian context, it shows that only one researcher did a study on MFL. Idrus (2015) studied about MFL among undergraduate students from Universiti Sains Islam Malaysia. The study focuses more on the implementation of FC by using video, SMS, and WhatsApp for class notification and discussion group for Physics subject. According to Embi, Nordin and Panah (2013), there are still needs in ML research focusing on MFL, especially in Malaysia to make it more accessible.

In ensuring the success of the FC approach, learning is one of the major parts that contribute a high impact on the learners in using technology. According to Houwer, Barnes-Holmes and Moors (2013), learning can be defined as a consequence of experience in behavior. Learning with technology is an instructor or learner who uses technology to promote learning and gaining knowledge from the learning activities (Mayer, 2010). Other than that, motivation becomes another important element to assist students in their learning, where during presenting the information, it helps them to complete learning tasks given by the teacher (Bingimlas, 2009; Grabe \& Grabe, 2007). According to Granito and Chernobilsky (2012), student's achievement and learning activities become more efficient if they have a high motivation to use and implement the technology, specifically using mobile devices. Besides, another important factor that contributes to the effectiveness of student learning is engagement in academic activities (Kuh, 2001). Therefore, to improve students' engagement, teachers and educational institutions such as school or tertiary level, should direct their energy and resources to the methodologies and technologies by shifting them into current practice (Hu \& Kuh, 2002).

Thus, the main purpose of this study is to find students' learning, motivation, and engagement towards using MFL. The effectiveness of an instructional tool can increase student engagement in the classroom and motivate them to enjoy learning activities. Therefore, the research question to be addressed in this study is; What is the students' perception in MFL in terms of motivation, learning, and engagement? 


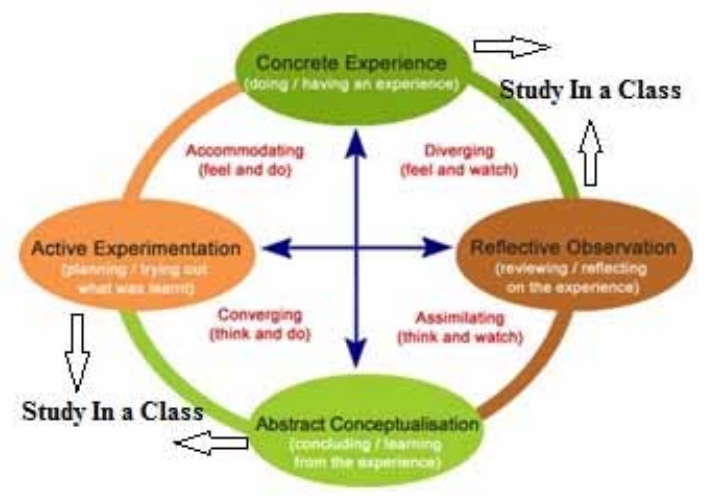

\section{THEORETICAL FRAMEWORK}

The study looked into Kolb's Learning Cycle as the foundation to strengthen the design of the mobile flipped classroom. Figure 1 illustrates the theoretical framework of the study utilizing Kolb's Learning Cycle. According to Idrus (2015), by using a mobile phone, it allows short and simple information to be cascaded down to the students without any constraint of time, space, and internet connectivity.

Kolb Experiential Learning Cycles was introduced by David Kolb in 1984 (McLeod, 2013) and it encourages the learning process through the experiences. Therefore, the MFL approach was implemented using Kolb's Learning Cycle which includes four (4) stages of the process as follows (Kori, 2013):

1. Concrete Experience: Learners explore the knowledge and information by using video, YouTube, social media or any other medium and established self-paced learning.

2. Reflective Observation: Learners engage with their learning by doing activities individually or with their peers through hands-on activity, group discussion, project-based, games, or experiments.

3. Abstract Conceptualization: Learners demonstrate and apply their understanding through presentation or project work, and shared with others.

4. Active Experimentation: Learners demonstrate what they have understood and learned while applying it into a real-life that can benefit their learning process.

From the theoretical framework, the mobile flipped approach can increase students' learning (Stone, 2012), where they can study about animation and multimedia better compare to traditional learning. The cognitive development will be elaborate more by using Kolb's Learning Cycle theory. Not only that, according to Dörnyei (2003), motivation is one of the main factors to contribute to educational success and was divided into two; intrinsic, when the driving comes from the individual or extrinsic when external rewards are the driving force to the behavior (Winhan, 2015).

In MFL, students are intrinsically motivated by exploring the mobile application available to understand or design their animation projects within their own pace. Besides, Rau, Gao and Wu (2006) explained that students are also extrinsically motivated when mobile phones and the internet are blended to facilitate their learning without any pressure. Therefore, this study shows that students are motivated intrinsically and extrinsically in experiencing MFL activity. Additionally, in MFL, students also develop their engagement in active learning activities conducted in class. They are actively contributing to the group discussion sharing new ideas, complete the tasks or projects given by the lecturer, and listening to the instructor's feedback to improve their understanding. At the same 
Figure 2. Aurasma application

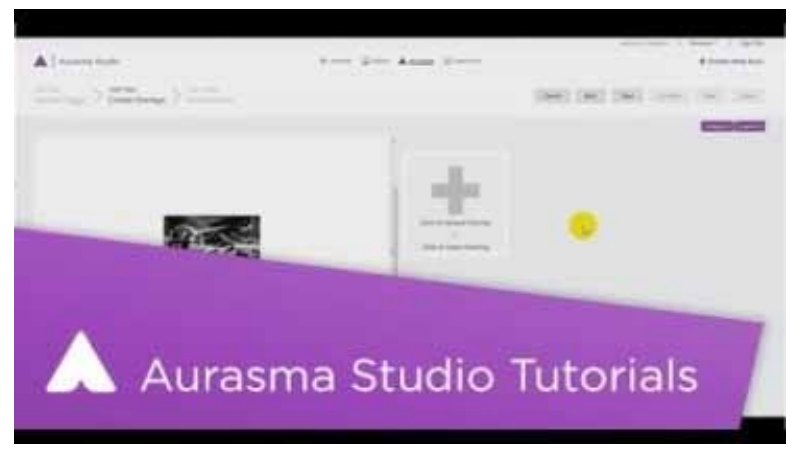

time, this combination also encourages students to engage in the learning process because they are free to explore knowledge at their own pace.

\section{METHODOLOGY}

In this study, the use of mobile flipped classroom is the major focus on learning computer animation and graphics using augmented reality (AR) application or better known as Aurasma. Figure 2 shows an example of the Ausrama application. It is available online and free to be installed in students' devices. The lecturer requested students to explore and create a project with AR technology element, before attending the class for further discussion and presentation.

This research applied homogenous purposive sampling by selecting 40 undergraduate final year students registered in multimedia and computer animation course. The idea of choosing purposive sampling is to have respondents with specific characteristics and relates to the topic being research. The selection was assisted by their teacher referring to the criteria of ability to use and manipulate online applications in creating the coursework. Etikan (2016) supported by stating purposive sampling is to concrete on respondents with selected characteristics in assisting researchers with relevant input. The selection was due to their exposure to technology and the ability to use AR was more advance compared to others. The research focused on undergraduate students because they have high exposure to mobile devices. The reason for selecting multimedia and animation course for this study is because the students have been exposed to AR technology and its related to their subject and project-based activities. The lecturers are also experts and skillful when using technology in the teaching and learning $(T \& L)$ process. Furthermore, it was conducted at one of the top industrial-based university in Kuala Lumpur. Respondents can access a free Wifi provided as long as they are within the university or hostel compound. Hence, this can be an added value and advantage to the researcher to research in MFL with selected students and lecturers due to their knowledge in using AR and facilities provided.

Students apply knowledge and skills gained from their experience to participate in the activity given by the teacher based on Kolb's Experiential Learning process. In this context, students start with concrete experience to gather as much as possible knowledge and information before attending the class by using Aurasma to experience AR. They carried out the task assigned by the teacher because the goal was to complete the tasks before the class starts. The students started engaging with their online learning, whether individually or collaboratively with their peers.

In the reflective observation stage, students were allowed to review knowledge gain from previous tasks and related experience gain in completing the tasks. Students presented their understanding and applied knowledge through project work or presentation related to AR, and shared with other peers. Next, during the abstract conceptualization stage, students interpreted and understand the relationships that existed among the new knowledge learned. In a mobile FC setting, students understand and relate 
the existence of AR and steps to create characters for the computer animation subject. While in the final stage, it allows students to absorb new knowledge and transform it into a projection on what is going to happen next or action needs to be taken to refine the way of completing the tasks. During the mobile FC session, students understand ways of creating a character by using mobile applications and at the same time, they learn to improve the steps to complete tasks assigned. The student experienced more tough tasks against established knowledge and encourages self-evaluation.

This study was conducted using a quantitative method, which a set of questionnaire survey distributed to the respondent once complete the Kolb's cycle. The researcher modifies existing questionnaires from Johnson (2013) and Zainuddin (2015). In Johnson (2013), it consists of 6 main questions with five-point Likert Scale questions on perception and usage of flipped learning. Meanwhile, the instrument from Zainuddin (2015) consists of 40 close-ended questionnaires, which are divided into three sections such as students' motivation, students' engagement, and students' learning. The questionnaires used a five-point Likert Scale and were tested with the I-CVI test by including a few experts. The experts are two coordinators and one experienced SME in a related field with more than six years handling educational technology matters. They are also trainers in encouraging technological tools into teaching activities. The five-point Likert Scale is 1- Strongly Disagree; 2- Disagree; 3- Neither Agree Nor Disagree; 4- Agree and 5- Strongly Agree. The result for all items in the questionnaires was I-CVI $>0.80(1.0>0.80)$ and considered evidence of good content validity for all items. Besides that, the researcher also conducts a pilot test to 10 students and the Cronbach Alpha value is 0.862 . In this context, the reliability of the questionnaires was proven and it's relevant to be used as a tool in this study (Field, 2009). SPSS version 20 was used to analyze the questionnaire. All data were analyzed using descriptive statistics such as percentages, mean (M) and standard deviation (SD). This analysis is appropriate to be used to analyze the value of the mean score that differed significantly.

\section{FINDINGS AND DISCUSSION}

To facilitate researchers in reporting the findings, the scores have been divided into three main categories, low, medium and high. For the response of 'strongly disagree' and 'disagree', it was considered as a negative response, while 'strongly agree' and 'agree' was reflected as a positive response. Furthermore, the feedback of 'neither agrees nor disagree' was considered as a neutral response. As recommended by Higgins, Thompson, Deeks, and Altman (2003), to interpret the data for reporting purposes, the percentage of $25 \%, 50 \%$, and $75 \%$ were considered as low, medium and high. The survey questions were divided into three main categories; Part A-students' motivation (item no 1-10), Part B-students' learning (item no 11-20) and Part C-students' engagement (item no 21-30).

\section{Students' Motivation}

10 items in the questionnaires examined students' motivation. The motivation elements were separated into intrinsic (item 1 -5) and extrinsic (item 6-10). Item 1 until item 9 shows more than $60 \%$ of students agree and strongly agree that FC gives a positive impact on their motivation. While for item 10, more than $70 \%$ disagree with the statement of they will be punished if not using AR in their learning activity. This shows that they are willing to use AR in their coursework. Table 1 summarizes findings on the application of AR in mobile MFL in terms of students' motivation.

In conclusion, the findings for item no 1-5 stated that the majority of the students intrinsically felt motivated to learn and involve in the MFL classroom. The findings also proved that the application of using mobile FC makes the student feel more motivated in their learning process because they enjoy, interested and understand better as compared to the traditional approach. Hence, apart from intrinsic motivation, the respondents were also extrinsically motivated to learn animation using the mobile FC approach because they intend to get a good grade, requirement course by the university 
Table 1. The percentage, M and SD of application of AR in MFL in term of students' motivation

\begin{tabular}{|c|c|c|c|c|c|c|c|}
\hline Item & \multicolumn{5}{|c|}{ Percentage (\%) } & \multirow[b]{2}{*}{$\mathbf{M}$} & \multirow[b]{2}{*}{ SD } \\
\hline Students' intrinsic motivation & $\begin{array}{l}\text { Strongly } \\
\text { Disagree }\end{array}$ & Disagree & $\begin{array}{l}\text { Neither } \\
\text { Agree } \\
\text { Nor } \\
\text { Disagree }\end{array}$ & Agree & $\begin{array}{c}\text { Strongly } \\
\text { Agree }\end{array}$ & & \\
\hline $\begin{array}{l}\text { 1. I felt excited while learning AR } \\
\text { in mobile FC. }\end{array}$ & 0 & 0 & 7.5 & 70 & 22.5 & 4.15 & 0.534 \\
\hline $\begin{array}{l}\text { 2. I was able to manage my } \\
\text { learning in mobile FC. }\end{array}$ & 0 & 0 & 0 & 70 & 30 & 4.30 & 0.464 \\
\hline $\begin{array}{l}\text { 3. I liked using mobile } \\
\text { applications because it was more } \\
\text { interesting. }\end{array}$ & 0 & 0 & 2.5 & 60 & 37.5 & 4.35 & 0.533 \\
\hline $\begin{array}{l}\text { 4. Using mobile applications } \\
\text { outside the class enabled me to } \\
\text { better understand the subject. }\end{array}$ & 0 & 0 & 2.5 & 62.5 & 35 & 4.33 & 0.526 \\
\hline $\begin{array}{l}\text { 5. I attended the class because I } \\
\text { wanted to explore new ideas. }\end{array}$ & 0 & 0 & 7.5 & 50 & 42.5 & 4.35 & 0.622 \\
\hline \multicolumn{8}{|l|}{ Students' extrinsic motivation } \\
\hline $\begin{array}{l}\text { 6. I learned animation because } \\
\text { it was a required course for my } \\
\text { program. }\end{array}$ & 0 & 7.5 & 22.5 & 50 & 20 & 3.83 & 0.844 \\
\hline $\begin{array}{l}\text { 7. I wanted to do well in this class } \\
\text { because it was important to show } \\
\text { my ability to my lecturer, family, } \\
\text { friends or others. }\end{array}$ & 0 & 5 & 7.5 & 50 & 37.5 & 4.20 & 0.791 \\
\hline $\begin{array}{l}\text { 8. I learned animation to find a } \\
\text { good job. }\end{array}$ & 2.5 & 10 & 22.5 & 40 & 25 & 3.75 & 1.031 \\
\hline $\begin{array}{l}\text { 9. The most satisfying thing for } \\
\text { me would be to get a good grade } \\
\text { in animation class. }\end{array}$ & 5.0 & 0 & 2.5 & 60 & 32.5 & 4.15 & 0.893 \\
\hline $\begin{array}{l}\text { 10. I learned AR in animation } \\
\text { because I would be punished } \\
\text { by my lecturer if I didn't. }\end{array}$ & 70 & 17.5 & 0 & 10 & 2.5 & 1.58 & 1.083 \\
\hline
\end{tabular}

and find an established career. Besides, other extrinsic motivations like to highlight some abilities to lecturers, family and friends also encourage students' motivation to learn animation with MFL.

The findings were similar to research done by Kumar, Jayasimman and Jebaseeli (2015) where they found that the majority of the students have positive perceptions towards using mobile devices, especially in using android applications for their learning activities. Based on the majority responses, it can be concluded that students feel motivated either intrinsically or extrinsically in experiencing MFL.

\section{Students' Learning}

There were 10 items examining students' learning from item 11 until 20. The scores show more than $60 \%$ of students positively agreed on implementing AR in classes to increase their attitude towards learning activities. Table 2 summarizes findings on the application of AR in MFL in terms of students' learning.

To the students' preference for using the MFL approach, the majority of them responded that they were satisfied with the way animation being taught during the classroom. Furthermore, they 
Table 2. The percentage, M and SD of application of AR in MFL in term of students' learning

\begin{tabular}{|c|c|c|c|c|c|c|c|}
\hline Item & & & ercentage $(c$ & & & & \\
\hline Students' Learning & $\begin{array}{l}\text { Strongly } \\
\text { Disagree }\end{array}$ & Disagree & $\begin{array}{l}\text { Neither } \\
\text { Agree } \\
\text { Nor } \\
\text { Disagree }\end{array}$ & Agree & $\begin{array}{c}\text { Strongly } \\
\text { Agree }\end{array}$ & $\mathbf{M}$ & SD \\
\hline $\begin{array}{l}\text { 11. I was satisfied with the way } \\
\text { AR technology was taught in the } \\
\text { classroom. }\end{array}$ & 0 & 0 & 2.5 & 77.5 & 20 & 4.18 & 0.447 \\
\hline $\begin{array}{l}\text { 12. I am now satisfied with } \\
\text { my performance in-class } \\
\text { assignments and tests. }\end{array}$ & 0 & 0 & 10 & 60 & 30 & 4.20 & 0.608 \\
\hline $\begin{array}{l}\text { 13. I now find activities in } \\
\text { animation lessons meaningful. }\end{array}$ & 0 & 0 & 5 & 60 & 35 & 4.30 & 0.564 \\
\hline $\begin{array}{l}\text { 14. Mobile FC gave me } \\
\text { opportunities for cooperation } \\
\text { and social interaction. }\end{array}$ & 0 & 0 & 37.5 & 42.5 & 20 & 3.83 & 0.747 \\
\hline $\begin{array}{l}\text { 15. I am now acquiring further } \\
\text { knowledge of AR and animation. }\end{array}$ & 0 & 0 & 20 & 60 & 20 & 4.00 & 0.641 \\
\hline $\begin{array}{l}\text { 16. I expect to perform well in } \\
\text { other subjects. }\end{array}$ & 0 & 0 & 10 & 50 & 40 & 4.30 & 0.649 \\
\hline $\begin{array}{l}\text { 17. I am sure I have the desire to } \\
\text { continue studying animation } \\
\text { focusing on AR. }\end{array}$ & 0 & 0 & 20 & 55 & 25 & 4.05 & 0.678 \\
\hline $\begin{array}{l}\text { 18. I discover that AR } \\
\text { technology matter is related to } \\
\text { my daily experiences. }\end{array}$ & 0 & 0 & 10 & 70 & 20 & 4.10 & 0.545 \\
\hline $\begin{array}{l}\text { 19. I realize that AR technology } \\
\text { gives opportunities for choice, } \\
\text { responsibility, and interpersonal } \\
\text { influence. }\end{array}$ & 0 & 0 & 10 & 70 & 20 & 4.10 & 0.545 \\
\hline $\begin{array}{l}\text { 20. I can now study and solve } \\
\text { problems in AR applications on } \\
\text { my own. }\end{array}$ & 0 & 0 & 22.5 & 72.5 & 5 & 3.83 & 0.501 \\
\hline
\end{tabular}

also responded the use of MFL encourages them to produce more quality artwork and improves their understanding of using animation applications. The findings were supported by Jacob and Isaac (2007), that learning through mobile devices promotes communities of practice where the students meet their friends through online for any kind of discussion. While Baker, Dede and Evans (2014) and Hanafi and Samsudin (2012), also agreed that using mobile learning can enhance communication skills among teachers and students via social media, email or and any other online channels. The finding and outcomes met the research objectives on students' perceptions in terms of learning using the mobile FC approach.

\section{Students' Engagement}

There were 10 items to examine students' engagement; item 21 until 30. Most of the item indicates that more than $50 \%$ of students agreed and strongly agreed with the use of MFL in increasing their engagement towards the subject. Table 3 summarizes findings on the application of AR in mobile flipped learning in terms of students' engagement. 
Table 3. The percentage, M and SD of application of AR in MFL in term of students' engagement

\begin{tabular}{|c|c|c|c|c|c|c|c|}
\hline Item & & & centage $(\%)$ & & & & \\
\hline Students' Engagement & $\begin{array}{l}\text { Strongly } \\
\text { Disagree }\end{array}$ & Disagree & $\begin{array}{l}\text { Neither } \\
\text { Agree } \\
\text { Nor } \\
\text { Disagree }\end{array}$ & Agree & $\begin{array}{l}\text { Strongly } \\
\text { Agree }\end{array}$ & $\mathbf{M}$ & SD \\
\hline $\begin{array}{l}\text { 21. When I was in this class, I } \\
\text { listened very carefully. }\end{array}$ & 0 & 0 & 0 & 60 & 40 & 5.40 & 6.280 \\
\hline $\begin{array}{l}\text { 22. I tried hard to do well in } \\
\text { this class. }\end{array}$ & 0 & 0 & 0 & 60 & 40 & 4.40 & 0.500 \\
\hline $\begin{array}{l}\text { 23. When I was in this } \\
\text { class, I participated in class } \\
\text { discussions. }\end{array}$ & 0 & 0 & 7.5 & 75 & 17.5 & 4.10 & 0.500 \\
\hline $\begin{array}{l}\text { 24. I enjoyed learning new } \\
\text { things in this class. }\end{array}$ & 0 & 0 & 0 & 50 & 50 & 4.50 & 0.500 \\
\hline 25. This class was fun. & 0 & 0 & 0 & 55 & 45 & 4.45 & 0.500 \\
\hline $\begin{array}{l}\text { 26. When we worked on } \\
\text { something in this class, I felt } \\
\text { interested. }\end{array}$ & 0 & 0 & 5 & 67.5 & 27.5 & 4.23 & 0.530 \\
\hline $\begin{array}{l}\text { 27. When I studied for this } \\
\text { class, I tried to connect what } \\
\text { I had learned with my own } \\
\text { experiences. }\end{array}$ & 0 & 0 & 12.5 & 60 & 27.5 & 4.15 & 0.622 \\
\hline $\begin{array}{l}\text { 28. I made up my examples } \\
\text { to help me understand the } \\
\text { important concept I was } \\
\text { studying for this class. }\end{array}$ & 0 & 0 & 12.5 & 70 & 17.5 & 4.05 & 0.552 \\
\hline $\begin{array}{l}\text { 29. During class, I asked } \\
\text { questions to help me learn. }\end{array}$ & 0 & 0 & 15 & 40 & 45 & 4.30 & 0.723 \\
\hline $\begin{array}{l}\text { 30. I tried to make whatever } \\
\text { we were learning as interesting } \\
\text { as possible. }\end{array}$ & 0 & 0 & 0 & 65 & 35 & 4.35 & 0.483 \\
\hline
\end{tabular}

From the findings, it can be concluded that students engage with the class activities. They are fun, enjoy learning new things and participated in the class discussion. Besides, they also took an extra effort to understand better by asking questions, connecting previous experience with what they have learned and tried hard to improve their performance on the subject. All items presented the positive perceptions of using MFL and this shows that students are engaged in the class. The feedback was supported by Brown (2011), stated that the ML method gave them more access to get additional information to facilitate the discussion during the classroom. This finding indicates that the students were happy and engaged in the learning process by using the MFL approach. This was supported by Baker, Dede and Evans (2014) and Kamarainen et al., (2013), which they stated the students were highly engaged with the use of mobile devices in the T\&L process. Other research also agreed by reporting that students feel more excited and engaged in their learning (Rogers et al., 2010; Wang et al., 2009 \& Al-Fahad, 2009). 


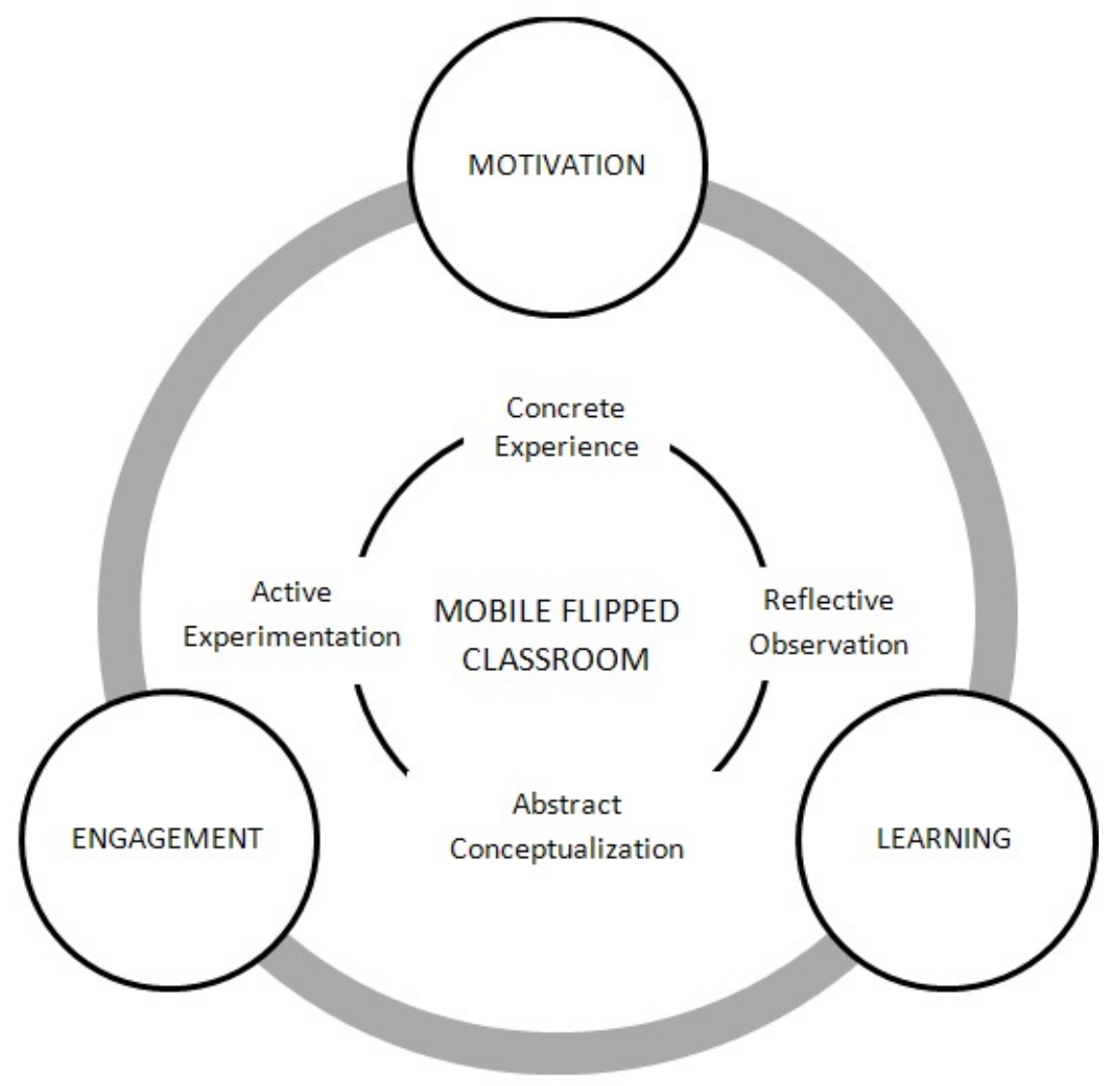

\section{CONCLUSION AND FUTURE IMPLICATIONS}

This study investigated the student's perception of the MFL approach in terms of their motivation, learning, and engagement. This study shows the student to practice the earlier cycle (concrete experience) outside the classroom by having a meaningful exploration and discussion among peers through social communication. Meanwhile, they are practicing the next cycle (reflective observation, abstract conceptualization, and active experimentation) during the class session with facilitation from the instructor and attending the assessment to measure their understanding of new knowledge. Figure 3 shows the research findings using MFL.

From the results analyzed, it can be concluded that the majority of the respondents have a positive perception of the MFL approach. This finding was supported by Kumar, Jayasimman and Jebaseeli (2015) research, which MFL method was able to develop learner's interest and engaged in the subject taught. A few studies show that using the FC method, it can improve students' motivation, engagement and learning style (Wihnan, 2015; Abeysekera \& Dawson, 2015). This study contributes development in educational approach, especially among Malaysian in improvising current teaching and learning pedagogy by adapting both AR and MFL. The lecturer can work closely with students during the classroom session because they have discovered the content outside the classroom. In other forms, this study encouraged lecturers to implement MFL into their T\&L activity. Besides, since MFL has just started its momentum in Malaysia, this study has a large prospect in the educational system because it can be one of the references to academic research and the Malaysian education system in 
enhancing the public's understanding, especially university students towards learning AR through MFL. Moreover, since the approach is new in Malaysia, the outcome of this study contributed a high impact to the university because they can review students' perception of the MFL approach and started to transform from a traditional to student-centered learning. Not only the university, but students also enjoy the new T\&L technique because this can be another option for them to start exploring AR technology and the implementation of MFL helps them study in a better way.

To enhance this study, further research is recommended to focus on a different course, age and targeted participants to obtain in-depth information on the implementation of the mobile FC approach in a different context. The policymakers and other authorities need to determine the use and implementation of MFL as a new pedagogical approach to extend more attention and attraction from students in ensuring an effective learning experience. 


\section{REFERENCES}

Abeysekera, L., \& Dowson, P. (2015). Motivation and cognitive load in the flipped classroom: Definition, rationale and a call for research. Higher Education Research \& Development, 34(1), 1-14. doi:10.1080/07294 360.2014 .934336

Al-Fahad, F. N. (2009). Students' Attitudes and Perceptions towards the Effectiveness of Mobile Learning in King Saud University, Saudi Arabia. The Turkish Online Journal of Educational Technology, 8(2), 111-119.

Baker, A., Dede, C., \& Evans, J. (2014). The 8 Essentials for Mobile Learning Success in Education. Qualcomm.

Bates, L. (2012). The Different Uses of E-Learning and M-Learning. Fractus Learning. https://www. fractuslearning.com/2012/09/12/e-learning-and-m-learning/

Bergmann, J., \& Sams, A. (2011). How the flipped classroom is radically transforming learning. The Daily Riff. http://www.thedailyriff.com/articles/how-the-flipped-classroom-is-radicallytransforming-learning-536.php

Bingimlas, K. A. (2009). Barriers to the Successful Integration of ICT in Teaching and Learning Environments: A Review of the Literature. Eurasia Journal of Mathematics, Science and Technology Education, 5(3), $235-245$. doi:10.12973/ejmste/75275

Brown, V. (2011). iClassroom, Learning on the Go. In M. Koehler \& P. Mishra (Eds.), Proceedings of Society for Information Technology \& Teacher Education International Conference 2011 (pp. 3048-3052). AACE.

Clark, D. (2012). Kolb's Learning Styles and Experiential Learning Model. Big Dog \& Little Dog's Performance Juxtaposition. http://www.nwlink.com/ donclark/hrd/styles/kolb.html

Dörnyei, Z. (2001). Teaching and researching motivation. Pearson Education.

El-Hussein, M. O. M., \& Cronje, J. C. (2010). Defining Higher Learning in the Higher Education Landscape. Journal of Educational Technology \& Society, 13(3), 12-21.

Embi, M. A., Mohd Nordin, N., \& Panah, E. (2013). Mobile Learning Research Initiatives in Malaysia. In M. A. Embi (Ed.), Mobile Learning: Malaysian Initiatives and Research Findings (pp. 9-18). Centre for Academic Advancement, UKM \& Department of Higher Education.

Etikan, I., Abubakar Musa, S., \& Alkassim, R. S. (2016). Comparison of Convenience Sampling and Purposive Sampling. American Journal of Theoretical and Applied Statistics, 5(1), 1-4. doi:10.11648/j.ajtas.20160501.11

Field, A. (2009). Discovering statistics using SPSS. SAGE. http://www.soc.univ.kiev.ua/sites/default/files/library/ elopen/andy-field-discovering- statistics-using-spss-third-edition-20091.pdf

Finnegan, M. (2015). Laptops, tablets and smart watches: The evolution of mobile computing. Computer World. https://www.computerworld.com/article/3412220/laptops--tablets-and-smartwatches--the-evolution-of-mobilecomputing.html\#slide7

Goh, P. S. C. (2012). The Malaysian Teacher Standard. A look at the challenges and implication for Teachers Educators. Educational Research for Policy and Practice, 1(2), 1-2. doi:10.1007/s10671-011-9107-8

Grabe, M., \& Grabe, C. (2007). Integrating technology for meaningful learning (5th ed.). Houghton Mifflin.

Granito, M., \& Chernobilsky, E. (2012). The Effect of Technology on a Student's Motivation and Knowledge Retention. NERA Conference Proceedings. https://pdfs.semanticscholar.org/b04c/b89a3fbc7756193b97be121ce0da9e1e8cba. pdf?_ga=2.119038729.1685750637.1595380289-1315578232.1595380289

Hamdan, N., McKnight, P., McKnight, K., \& Arfstrom, K. M. (2013). The flipped learning model: A white paper based on the literature review titled A Review of Flipped Learning. Flipped Learning Network.

Hanafi, H. F., \& Samsudin, K. (2012). Mobile Learning Environment System (MLES): The Case of Androidbased Learning Application on Undergraduates' Learning. International Journal of Advanced Computer Science and Applications, 3(3), 12-20.

Higgins, J. P., Thompson, S. G., Deeks, J. J., \& Altman, D. G. (2003). Measuring inconsistency in meta-analyses. BMJ (Clinical Research Ed.), 327(7414), 557-560. doi:10.1136/bmj.327.7414.557 PMID:12958120 
Houwer, J. D., Barnes-Holmes, D., \& Moors, A. (2013). What is Learning? On the nature and merits of a functional definition of learning. Psychonomic Bulletin \& Review, 20(4), 631-642. doi:10.3758/s13423-0130386-3 PMID:23359420

Hu, S., \& Kuh, G. D. (2002). Being (dis)engaged in educationally purposeful activities: The influences of student and Institutional characteristics. Research in Higher Education, 43(5), 555-575. doi:10.1023/A:1020114231387

Idrus, R. (2015). The Mobile Learning Flipped Classroom. In K. Psarris (Ed.), Proceedings of the 2015 International Conference on Education and Modern Educational Technologies (EMET2015) (pp. 65-68). Recent Advances in Education and Educational Technology. http://www.wseas.us/e-library/conferences/2015/ Malaysia/EDU/EDU-10.pdf

Jacob, S. M., \& Issac, B. (2007). Mobile Learning Culture and Effects in Higher Education. IEEE Multidisciplinary Engineering Education Magazine, 2(2), 17-20.

Johnson, G. B. (2013). Students Perception on the Flipped Classroom (Unpublished Master Dissertation). The University of British Columbia.

Kamarainen, A. M., Metcalf, S., Grotzer, T., Browne, A., Mazzuca, D., Tutwiler, M. S., \& Dede, C. (2013). EcoMOBILE: Integrating augmented reality and probe ware with environmental education field trips. Computers \& Education. http://ecomuve.gse.harvard.edu/publications/1s2.0-S0360131513000572-main.pdf

Kori, J. (2013). Flipped learning model for effective blended learning. Learning and Skills Group. https:// learningandskillsgroup.ning.com/events/flipped-learning-for-effective-blended-learning?xg_source=activity

Kuh, G.D. (2001). Assessing what really matters to student learning. Inside the National Survey of Student Engagement Change, 33(3), 10-17.

Kumar, B. S., Jayasimman, L., \& Jebaseeli, N. (2015). A Comparative Study on Mobile Devices for Learning. International Research Journal of Engineering and Technology, 2(3), 1392-1395.

Lage, M. J., Platt, G. J., \& Treglia, M. (2000). Inverting the Classroom: A gateway to creating an inclusive learning environment. The Journal of Economic Education, 31(1), 30-43. doi:10.1080/00220480009596759

Mayer, R. E. (2010). Learning With Technology. In The Nature of Learning: Using Research to Inspire Practice. OECD. doi:10.1787/9789264086487-10-en

McLeod, S. (2013). Kolb Learning Styles and Experiential Learning Cycle. Simply Psychology. https://www. simplypsychology.org/learning-kolb.html

Milman, N. B. (2012). The flipped classroom strategy: What is it and how can it best be used? Distance Learning, 9(3), 85-87.

Milrad, M., Wong, L. H., Sharples, M., Hwang, G. J., Looi, C. K., \& Ogata, H. (2013). Seamless learning: An international perspective on next generation technology enhanced learning. In Z. L. Berge \& L. Y. Muilenburg (Eds.), Handbook of mobile learning (pp. 95-108). Routledge.

Morgan, H. (2014). Focus on Technology: Flip Your Classroom to Increase Academic Achievement. Childhood Education, 90(3), 239-241.

Nagel, D. (2013). Report: Students Use Smart Phones and Tablets for School, Want More. The Journal. https:// thejournal.com/articles/2013/05/08/report-students-use-smart-phones-and-tablets-for-school-want-more.aspx

Nederveld, A., \& Berge, Z. L. (2015). Flipped learning in the workplace. Journal of Workplace Learning, 27(2), 162-172. doi:10.1108/JWL-06-2014-0044

Norman, H., Nordin, N., Din, R., Ally, M., \& Dogan, H. (2015). Exploring the Roles of Social Participation in Mobile Social Media Learning: A Social Network Analysis. International Review of Research in Open and Distributed Learning, 16(4), 205-224. doi:10.19173/irrodl.v16i4.2124

Rau, P. P., Gao, Q., \& Wu, L. (2006). Using Mobile Communication Technology in High School Education: Motivation, Pressure, and Learning Performance. Computers \& Education, 50(1), 1-22. doi:10.1016/j. compedu.2006.03.008 
Rogers, Y., Connelly, K., Hazlewood, W., \& Tedesco, L. (2010). Enhancing learning: A study of how mobile devices can facilitate sense-making. Personal and Ubiquitous Computing, 14(2), 111-124. doi:10.1007/s00779009-0250-7

Sams, A., \& Bergmann, J. (2012). Flip your classroom: Reach every student in every class every day. International Society for Technology in Education (ISTE).

Sharples, M., Taylor, J., \& Vavoula, G. (2007). A theory of learning for the Mobile Age. In R. Andrews \& C. Haythornthwaite (Eds.), The Sage Handbook of E-learning Research (pp. 221-247). SAGE. doi:10.4135/9781848607859.n10

Shibley, I. (2014). Putting the Learning in Blended Learning. Blended \& Flipped: Exploring New Models for Effective Teaching and Learning. Magna Publications. A Magna Publication. https://www.ufv.ca/media/assets/ teaching--learning-centre/blended-and-flipped-specialreport.pdf

Simpson, V., \& Richards, E. (2015). Flipping the classroom to teach population health: Increasing the relevance. Nurse Education in Practice, 15(3), 162-167. doi:10.1016/j.nepr.2014.12.001 PMID:25707309

Stone, B. B. (2012). Flip Your Classroom to Increase Active Learning and Students Engagement. 28th Annual Conference on Distance Teaching and Learning Proceedings. https://www.uwex.edu/disted/conference/ Resource_library/proceedings/56511_2012.pdf

Touchton, M. (2015). Flipping the Classroom and Student Performance in Advanced Statistics: Evidence from a Quasi-Experiment. Journal of Political Science Education, 11(1), 28-44. doi:10.1080/15512169.2014.985105

Tune, J. D., Sturek, M., \& Basile, D. P. (2013). Flipped classroom model improves graduate student performance in cardiovascular, respiratory, and renal physiology. Advances in Physiology Education, 37(4), 316-320. doi:10.1152/advan.00091.2013 PMID:24292907

Wang, M., Shen, R., Novak, D., \& Pan, X. (2009). The Impact of Mobile Learning on Experts Learning Behaviours and Performance: Report from a Large Blended Classroom. British Journal of Educational Technology, 40(4), 673-695. doi:10.1111/j.1467-8535.2008.00846.x

Wihnan, J. (2015). Flipped Learning and the Motivational Framework of Students (Unpublished Master Dissertation). University of Victoria.

Yusoff, Z., \& Sunar, M. S. (2014). Augmented Reality: A Survey in Educational Environment. International Journal of Interactive Digital Media, 2(1), 1-8.

Zainuddin, Z. (2015). Perceptions on The Use of A Flipped Classroom for English Language Learners at a University in Acheh (Unpublished Master Dissertation). University of Malaya.

Siti Hajar Halili $(P h D)$ is a Senior Lecturer in Department of Curriculum \& Instructional Technology.

Norharyanti Mohsin is a Postgraduate Student in Department of Curriculum \& Instructional Technology, in the Faculty of Education at the University of Malaya, Kuala Lumpur. Her areas of specialisation are mobile learning and flipped classroom.

Rafiza Abdul Razak (PhD) is Senior Lecturer in Department of Curriculum \& Instructional Technology, in the Faculty of Education at the University of Malaya, Kuala Lumpur. Her specializations encompass developing of electronic based professional development, teaching and learning innovation and designing e-curricular for digital native. 